\title{
PEMANFAATAN NIRA AREN MENJADI BIOETANOL UNTUK BAHAN BAKAR EMULSI YANG RAMAH LINGKUNGAN
}

\author{
Anita R. Ibrahim ${ }^{1)}$, Hanny F. Sangian ${ }^{1)}$, Handy I. R. Mosey ${ }^{1}$, Ronny Purwadi ${ }^{2}$ \\ ${ }^{1)}$ Program Studi Fisika FMIPA UNSRAT Manado, 95115 \\ ${ }^{2)}$ Jurusan Teknik Kimia, Fakultas Teknologi Industri, Institut Teknologi Bandung, 40132
}

\begin{abstract}
This research purpose is to make gasohol fuel made from a mixture of ethanol and Pertamax as well as ethanol and pertalite. Ethanol used for this mixture has been through the process of reflux fermentation and distillation. Then the ethanol distillation process is carried out to obtain purity above $80 \%$. The next stage is the process of mixing ethanol with Pertalite and Pertamax where the concentration of ethanol that will be mixed with Pertamax and Pertalite to become gasohol varies from $80 \%$ to $98 \%$ ethanol at $1 \%$ intervals. The Pertalite and Pertamax used for each sample was $7 \mathrm{ml}$ while ethanol was added while shaking with a circular motion of the test tube until the solution became one phase. Using $80 \%$ ethanol in the mixture produces a Pertalite: pure ethanol: water ratio of 1: 11.65: 2.91 (in volume units), while $98 \%$ ethanol in the mixture produces a Pertalite: pure ethanol: water ratio of 1: 0.007 : 0.001 (in units of volume). For Pertamax, the minimum ethanol concentration mixed with Pertamax into a single-phase emulsion is $88 \%$ with a composition of 1: 5.91: 0.81 .
\end{abstract}

Keywords: ethanol, Pertalite, Pertamax.

\begin{abstract}
ABSTRAK
Penelitian ini bertujuan untuk membuat bahan bakar gasohol dengan beberapa campuran antara etanol dan Pertamax juga etanol dan Pertalite. Tahapan yang pertama yaitu pembuatan etanol dari nira aren yang sudah terfermentasi. Kemudian dilakukan proses destilasi etanol untuk mendapatkan kemurnian di atas $80 \%$. Tahapan selanjutnya yaitu proses pencampuran etanol dengan Pertalite dan Pertamax dimana konsentrasi etanol yang akan dicampur dengan Pertamax dan Pertalite untuk menjadi gasohol divariasikan mulai dari etanol $80 \%$ sampai $98 \%$ dengan interval 1\%. Pertalite dan Pertamax yang digunakan untuk setiap sampel adalah $7 \mathrm{ml}$ sementara untuk etanol ditambahkan sambil diputar dalam tabung reaksi sampai larutan menjadi satu fasa. Dengan menggunakan etanol $80 \%$ dalam campuran menghasilkan perbandingan Pertalite : etanol murni : air adalah 1: 11,65: 2,91 (dalam satuan volume), sementara untuk etanol $98 \%$ dalam campuran menghasilkan perbandingan Pertalite : etanol murni : air adalah 1: 0.007: 0.001 (dalam satuan volume). Untuk Pertamax, konsentrasi etanol minimum yang dicampur dengan Pertamax menjadi emulsi satu fase adalah 88\% dengan komposisi 1: 5.91: 0.81. Konsentrasi etanol maksimum yang dicampur dengan Pertamax menjadi emulsi satu fase adalah 97\% dengan perbandingan volume Pertamax : etanol murni : air adalah 1: 0,41: 0,02.
\end{abstract}

Kata kunci : etanol, Pertalite, Pertamax. 


\section{PENDAHULUAN}

Saat ini para ahli berusaha untuk mmengembangkan sumber bahan terbarukan lingnoselulosa dan pati untuk di ubah menjadi bahan yang lebih berharga dengan cara preatreatment.(Sangian et al. $2018^{\mathrm{a}}$ ); (Sangian et al. 2018 ); (Sangian et al. $\left.2018^{\mathrm{c}}\right)$.

Jumlah penduduk dunia terus mengalami peningkatan setiap tahunnya, begitu juga dengan kebutuhan energi yang digunakan. Ketersediaan sumber energi tak terbaharui (bahan bakar fosil) semakin menipis dan langka. Oleh sebab itu diperlukan upaya-upaya pengembangan teknologi yang mampu mensuplai kebutuhan energi pengganti dan mampu mengurangi masalah yang berkaitan dengan masalah lingkungan. Salah satu upaya yang dapat dilakukan adalah dengan mengembangkan sumber energi terbarukan yang ramah lingkungan. Produksi bahan bakar minyak bumi (fosil) yang tidak dapat mengimbangi besarnya permintaan bahan bakar minyak menjadi permasalahan utama energi di seluruh dunia. Selain itu pengaruh pemanasan global yang ditimbulkan juga menjadi salah satu faktor kekhawatiran karena penggunan bahan bakar fosil merupakan faktor utama dalam peningkatan konsentrasi $\mathrm{CO}_{2}$ di atmosfer yang mengakibatkan terjadinya pemanasan global (Demirbas, Bozbas, \& Balat, 2004). Dengan membatasi penggunaan bahan bakar fosil akan mengurangi kadar polutan hasil produksi $\mathrm{CO}_{2}$.

Bioetanol (etil alkohol, alkohol gandum, $\mathrm{CHCH}_{2} \mathrm{OH}$ atau ETOH) adalah bahan bakar cair yang dapat diproduksi dari beberapa bahan baku biomassa dengan teknologi konversi yang berbeda. Menurut (Martín, Galbe, Wahlbom, Hahn-Hägerdal, \& Jönsson, 2002) bioetanol telah diakui sebagai bahan bakar alternatif dari sumber daya hayati yang lebih ramah lingkungan dan dapat diperbaharui. Bahan yang paling umum digunakan sebagai bahan baku untuk produksi etanol adalah jagung, tebu dan gandum (Balat, Balat, \& Öz, 2008). Pada tahun 2006, produksi global bioetanol mencapai 13,5 milyar gallon dibandingkan pada tahun 2005 yaitu 12,1 milyar gallon. Sekitar $60 \%$ produksi bioetanol berasal dari tebu dan $40 \%$ dari tanaman lain (Dufey, 2006).

(Hsieh et al., 2002) melakukan eksperimen untuk menguji kinerja mesin dan emisi polutan dari mesin komersial menggunakan bahan bakar campuran etanol-bensin dengan berbagai tingkat campuran $(0 \%, 5 \%, 10 \%, 20 \%, 30 \%)$. Sifat bahan bakar dari bahan bakar 
campuran etanol-bensin pertama diperiksa dengan metode standar ASTM (American Society for Testing and Material).

Di Sulawesi Utara, etanol didapat dari pohon aren (Arenga prinnata) yang merupakan pohon palem lokal dan nira yang dihasilkan disebut dengan saguer. Hasil studi menunjukkan bahwa seratus liter nira dimasukkan di dalam plastik untuk difermentasi selama 4-5 hari. Dengan menerapkan destilasi reflux, maka etanol yang dihasilkan bisa mencapai kemurnian 96\% tergantung pada suhu kolom (Sangian et al., 2017)

Penelitian ini diarahkan untuk membuat bahan bakar campuran dengan beberapa campuran antara etanol, Pertalite, dan air dan juga campuran antara etanol, Pertamax dan air menjadi larutan satu fasa. Etanol yang akan dicampur dengan Pertalite dan Pertamax untuk menjadi gasohol divariasikan mulai dari etanol dengan konsentrasi $80 \%$ sampai $98 \%$. Produk ini yang dinamakan sebagai aqueos gasohol satu fasa dan dapat diaplikasikan pada mesin bakar konvensional.

\section{METODOLOGI PENELITIAN}

\section{Alat}

Alat yang digunakan: Gelas ukur Alcohol meter Botol / wadah sebagai tempat gasohol Pipet tetes dan alat destilasi refluks untuk pembuatan etanol.

\section{Bahan}

Bahan yang digunakan: Etanol (Terfermentasi dari nira aren), BBM jenis pertamax dan BBM jenis pertalite.

\section{Prosedur pembuatan etanol pada proses destilasi}

Pembuatan etanol $96 \%$ diproses oleh alat destilasi refluks. Hasil fermentasi dari nira aren dimasukkan ke dalam boiler dan dipanaskan untuk memisahkan air dari bioetanol dengan suhu dalam boiler dikontrol termometer. Pada proses pemanasan, uap yang dihasilkan naik ke kolom dan mengembun, nantinya menetes ke bawah. Proses akan terus dilakukan sampai bioetanol mencapai kemurnian 95\% sampai $96 \%$. Pada proses pemisahan, dilakukan pengontrolan jumlah refluks uap pada kolom. Uap yang naik pada atas kolom dihubungkan dengan kondensor untuk mengubah kembali uap menjadi cairan. Cairan ini merupakan hasil dari proses destilasi refluks bioetanol, yang nantinya digunakan pada proses pembuatan emulsi.

\section{Prosedur Pembuatan Emulsi}

Dalam proses pembuatan emulsi akan dilakukan secara manual yaitu dengan mencampurkan secara langsung etanol dengan pertalite dan pertamax. 
Alat dan bahan berupa gelas ukur, alat ukur konsentrasi, etanol, air dan Pertalite disiapkan untuk proses pencampuran lalu Konsentrasi etanol $80 \%$ sampai $98 \%$ diukur dengan menggunakan Alcohol Meter. Setelah itu, Pertalite atau pertamax dimasukkan ke dalam gelas ukur (wadah pencampuran) dengan volume $7 \mathrm{ml}$ untuk diproses menjadi gasohol. Kemudian Etanol dengan kemurnian $80 \%$ ditambahkan langsung ke dalam gelas ukur yang berisi Pertalite atu pertamax secara perlahan dan dilarutkan sampai kedua cairan bercampur menjadi satu fasa. Langkah 4 dilakukan kembali untuk etanol dengan kemurnian $81 \%$ sampai 98\% ke dalam gelas ukur dengan volume bahan bakar $7 \mathrm{ml}$. Proses ini berlangsung sampai kedua cairan yaitu etanol dan pertalite atau pertamax menjadi terlarut dan bercampur menjadi satu fasa. Pencampuran dilakukan ulang apabila terjadi kesalahan, seperti menuangkan etanol terlalu banyak pada konsentrasi yang tinggi sehingga ketepatan volume gasohol yang menjadi satu fasa tidak tepat.

\section{HASIL DAN PEMBAHASAN}

Pemisahan Etanol Dengan Air Dengan Menggunakan Destilasi Refluks

Penelitian dimulai pada proses pemanasan cap tikus dengan suhu awal yang terbaca oleh sensor adalah $28,8^{\circ} \mathrm{C}$. Setelah selang waktu 105 menit sejak awal proses separasi, suhu naik menjadi $76,5^{\circ} \mathrm{C}$ dan etanol mulai menetes keluar dari ujung kondensor. Selanjutnya dalam waktu 14 menit, suhu menjadi $79^{\circ} \mathrm{C}$ dan volum etanol pada kolektor (erlen meyer) menjadi $100 \mathrm{ml}$, kemudian itu diukur tingkat kemurniannya dengan menggunakan alat uji konsentrasi, sehingga didapatkan etanol dengan kemurnian $87,5 \%$ sebagai produk awal pada proses destilasi. Pada suhu kedua yaitu $81^{\circ} \mathrm{C}$, didapatkan etanol dengan kemurnian $85 \%$ dalam waktu 9 menit.

Setelah beberapa saat proses berlangsung dilakukan pengontrolan pada suplai panas sehingga suhu turun menjadi $79,6^{\circ} \mathrm{C}, 79^{\circ} \mathrm{C}$ dan naik $79,5^{\circ} \mathrm{C}$, dengan kemurnian etanol yang didapatkan masing-masing adalah: $80 \%, 87.5 \%$, dan 89\%. Selanjutnya konsentrasi etanol terus meningkat hingga mencapai $96 \%$ pada suhu $78^{\circ} \mathrm{C}$. Setelah itu suhu kembali naik hingga volume etanol dalam (liquor) habis dan mencapai titik didih molekul air, yang mengakibatkan menurunnya konsentrasi etanol.

Pencampuran Etanol dan Gasoline (Pertalite dan, Pertamax

proses pencampuran diawali dengan mempersiapkan $7 \mathrm{ml}$ Pertalite yang akan dimasukkan ke dalam gelas 
ukur. Etanol (hidrat) berkonsentrasi $80 \%$ ditambahkan ke dalam gelas ukur secara perlahan dengan volume $5 \mathrm{ml}$, Pada proses tersebut terlihat bahwa Pertalite mulai mengambang di atas permukaan larutan etanol dalam gelas ukur, artinya baru sebagian Pertalite yang tercampur dalam etanol. Pada penambahan etanol dengan volume $7 \mathrm{ml}$, jumlah volume Pertalite yang terpisah masih sama dengan proses sebelumnya. Setelah pencampuran dengan beberapa komposisi, larutan etanol dan Pertalite dapat menjadi satu fasa pada penambahan volume etanol sebesar 102 $\mathrm{ml}$. Sehingga produk tersebut dinyatakan sebagai gasohol E-93 dengan masingmasing persentase yaitu $81.6 \%$ untuk etanol, $20.4 \% \mathrm{H}_{2} \mathrm{O}$ dan $7 \%$ pertalite.

Gasohol E-93 artinya adalah 93 bagian etanol berair $(102 \mathrm{ml}$ dibagi dengan $109 \mathrm{ml}$ Pertalite dikali 100\%) dan 7 bagian Pertalite. Untuk persentase etanol dalam gasohol didapat melalui volume etanol murni (ml) dikali dengan volume total larutan (volume etanol yang ditambahkan + volume awal gasoline) dibagi $100 \%$, sedangkan persentase $\mathrm{H}_{2} \mathrm{O}$ diperoleh dari volume $\mathrm{H}_{2} \mathrm{O}$ dalam etanol dikali dengan volume total larutan kemudian dibagi 100\%. Hal ini berlaku untuk semua konsentrasi etanol pada proses pencampuran.
Kemudian proses pencampuran etanol dan Pertalite dilanjutkan untuk etanol berkonsentrasi 95\% hingga 98\%. Pada kemurnian $95 \%$ dilakukan penambahan etanol dengan volume sebanyak $2 \mathrm{ml}$ pada $7 \mathrm{ml}$ Pertalite dalam gelas ukur dan terlihat bahwa kedua substansi sudah hampir tercampur menjadi satu fasa. Hal ini disebabkan oleh konsentrasi etanol yang tinggi sehingga kedua larutan lebih mudah untuk tercampur. Setelah penambahan volume etanol sebesar $3 \mathrm{ml}$, semua komponen (etanol, air dan Pertalite) menjadi satu fasa dan dinyatakan sebagai gasohol E-30 dengan masing-masing persentase yaitu $2,85 \%$ untuk etanol, $0,15 \% \mathrm{H}_{2} \mathrm{O}$ dan $7 \%$ Pertalite Sedangkan untuk etanol dengan kemurnian 98\%, terdapat sedikit hambatan dalam penentuan ketercampuran kedua larutan, ini diakibatkan oleh konsentrasi etanol yang sangat tinggi Sehingga dibutuhkan ketelitian pada saat proses pencampuran. Pada etanol dengan kemurnian $98 \%$ hanya dibutuhkan volume sebanyak $0,5 \mathrm{ml}$ ke dalam $7 \mathrm{ml}$ Pertalite untuk menjadi satu fasa dan dinyatakan sebagai gasohol E-6 dengan masing-masing persentase yaitu 0,049\% untuk etanol, $0,01 \% \mathrm{H}_{2} \mathrm{O}$ dan $7 \%$ Pertalite. Tabel 4.2 menunjukkan komposisi bahan bakar campuran 
Pertalite, etanol murni dan air dalam larutan satu fasa.

Untuk Pertamax etanol berkonsentrasi $\quad 88 \% \quad$ dilakukan pencampuran dengan penambahan volume pada gelas ukur sebesar $12 \mathrm{ml}$, sehingga Pertamax yang masih terpisah yaitu $18 \mathrm{ml}$ dari $19 \mathrm{ml}$ volume awal, yang artinya $1 \mathrm{ml}$ telah terlarut dalam proses tersebut. Setelah beberapa penambahan volume etanol yang berbeda, dapat disimpulkan bahwa jumlah Pertamax dalam gelas ukur semakin berkurang sesuai dengan penambahan etanol. Untuk pencampuran 88\% etanol dengan $7 \mathrm{ml}$ Pertamax menjadi satu fasa pada penambahan volume $95 \mathrm{ml}$ etanol. Sehingga dinyatakan sebagai gasohol E-92 dengan masingmasing persentase yaitu $41,36 \%$ untuk etanol, 5,64\% $\mathrm{H}_{2} \mathrm{O}$ dan $7 \%$ Pertamax.

Pada kemurnian 95\% dilakukan penambahan etanol dengan volume sebanyak $11 \mathrm{ml}$ pada $7 \mathrm{ml}$ Pertamax dalam gelas ukur dan terlihat bahwa kedua substansi sudah tercampur menjadi satu fasa. Hal ini disebabkan oleh konsentrasi etanol yang tinggi sehingga kedua larutan lebih mudah untuk tercampur dengan masing-masing persentase yaitu $10,45 \%$ untuk etanol, $0,55 \% \mathrm{H}_{2} \mathrm{O}$ dan $7 \%$ Pertamax. Sedangkan untuk etanol dengan kemurnian 97\%, dikarenakan konsentrasi etanol yang juga sangat tinggi dibutuhkan ketelitian pada saat proses pencampuran. Pada Etanol dengan kemurnian $97 \%$ hanya dibutuhkan sebanyak $2 \mathrm{ml}$ ke dalam $7 \mathrm{ml}$ Pertamax untuk menjadi satu fasa dengan masingmasing persentase yaitu $1,94 \%$ untuk etanol, $0,06 \% \mathrm{H}_{2} \mathrm{O}$ dan $7 \%$ Pertamax.

Seperti yang ditunjukkan dalam data, perubahan konsentrasi etanol mempengaruhi secara signifikan terhadap komposisi atau jumlah Pertalite/Pertamax, etanol, dan air. Pembentukan gasohol dalam satu fasa harus dalam komposisi yang tepat antara Pertalite/Pertamax, etanol murni, dan air. Jika jumlah etanol kurang dari komposisi minimum campuran satu fasa tidak dapat dibentuk. Gaya gravitasi yang bekerja pada molekul etanol berair lebih besar daripada gaya tarik parsial antara kutub gasoline dan etanol. Semakin rendah kemurnian etanol dengan gasoline membentuk gasohol semakin kecil kemungkinan etanol encer dan gasoline membentuk emulsi dalam satu fasa. Secara umum, komposisi etanol yang dilarutkan di dalam Pertamax lebih tinggi dibandingkan dengan Pertalite.

\section{Definisi Tegangan Permukaan}

Dalam proses pencampuran, etanol (hidrat) berperan aktif sebagai surfaktan dan bertindak sebagai zat pelarut terhadap 
hidrokarbon, termasuk gasoline (Powers et al., 2001). Penambahan surfaktan dalam larutan dapat menyebabkan turunnya tegangan permukaan molekul air (McDowell \& Powers, 2003). Tercampurnya larutan etanol dan gasoline menjadi satu fasa dipengaruhi oleh gugus hidrofilik dan lipofilik yang dimiliki oleh surfaktan, dimana gugus hidrofilik pada surfaktan bersifat polar sehingga mudah bersenyawa dengan air, sedangkan gugus lipofilik bersifat non polar yang dapat bersenyawa dengan minyak. Bila etanol telah melebihi volume gasoline maka tegangan permukaan larutan menjadi konstan walaupun konsentrasi surfaktan ditingkatkan.

\section{Analisis Grafik Triangular pada}

\section{Pertalite dan Pertamax}

Dari data hasil proses pencampuran antara Pertalite, etanol, air dan pencampuran Pertamax, etanol, air menjadi satu fasa dapat dilihat dalam diagram triangular di bawah ini. Percobaan dilakukan pada suhu $30^{\circ} \mathrm{C}$ dan tekanan atmosfer 1 atm. Titiktitik pada ruas kanan yang dihasilkan menunjukkan jumlah persentase komposisi pencampuran ketika menjadi satu fasa. Bentuk dua grafik hampir serupa tetapi konsentrasi etanol yang dicampur satu fasa berbeda di mana Pertalite larut sepenuhnya pada dengan etanol $80 \%$, sedangkan Pertamax hanya pada etanol dengan konsentrasi $88 \%$. Area grafik dimana kondisi yang masih terpisah menjadi dua fasa terletak di sisi kiri pada grafik, sedangkan yang menunjukkan satu fasa ada di sisi kanan seperti yang ditunjukkan pada gambar. Kisaran komposisi etanol murni, Pertalite, dan air di mana ketiganya terlarut sepenuhnya masing-masing adalah 0,69-74,87\%, 6,43$99,21 \%$, dan 0,10-18,70\%. Kadar air tertinggi yang dicampur ke dalam Pertalite adalah sebesar $18,70 \%$ yang dicampur dengan menggunakan etanol konsentrasi $80 \%$ yang merupakan konsentrasi paling sedikit.

Ketika Pertamax dilakukan pencampuran seperti pada Pertalite, komposisi berubah secara signifikan dan konsentrasi etanol paling sedikit berbeda dibandingkan dengan Pertalite. Ketika etanol $88 \%$ digunakan, Pertamax, etanol murni dan air tercampur sempurna dengan komposisi $12,96 \%, 76,59 \%$, dan 10,45\% yang merupakan konsentrasi paling sedikit. Kisaran komposisi Pertamax, etanol murni, dan air dimana mereka dicampur dalam satu fasa adalah 12,99\%$78,25 \%, \quad 21,13 \%-76,62 \%$, dan 0,63\%10,39\%. Pada etanol $95 \%$ dan $96 \%$ terlarut dengan sempurna pada komposisi 
38,94\% (Pertamax), 58,02\% (etanol), dan

\section{KESIMPULAN}

Gasohol berair tersusun oleh bensin dengan parameter RON 90 (Pertalite) dan 92 (Pertamax) dapat dicampur dengan baik di mana kemurnian etanol di bawah $98 \%$. Hasilnya menunjukkan bahwa etanol yang konsentrasinya $80 \%-98 \%$ dilarutkan sepenuhnya dengan bahan bakar dalam komposisi yang tepat. Rentang komposisi Pertalite, etanol murni, dan air dimana membentuk campuran satu fasa menggunakan etanol dengan konsentrasi $80 \%-98 \%$ adalah $9,46 \%-99,21 \%, \quad 0,69 \%-76,94 \%, \quad$ dan 0,10\%-13,59\% sedangkan campuran Pertamax, etanol murni, dan air yang menggunakan etanol 88\%-97\% adalah $12,96 \%-77,76 \%, 21,54 \%-76,58 \%$ dan 0,70\%-10,45\%. Ditemukan bahwa perubahan konsentrasi etanol dapat mempengaruhi secara signifikan komposisi bahan bakar, etanol, dan air dalam membentuk gasohol satu fasa. Penambahan etanol setelah satu fasa terbentuk tidak dapat memisahkan komponen bahan bakar dan etanol berair tetapi jumlah etanol yang lebih sedikit untuk menjadi bahan bakar emulsi berair satu fasa tidak akan tercapai. Ditemukan bahwa parameter
$3,04 \%$ (air) dan 70,08\%, 28,73\%, dan 1,1

bahan bakar dan destilasi berubah dari etanol murni dan bahan bakar yang disebabkan oleh adanya etanol dan sebagian kecil air tetapi masih dalam kisaran yang diizinkan sebagai bahan bakar.

\section{SARAN}

Penelitian ini perlu dikembangkan pada tahap uji coba bahan bakar gasohol berair pada mesin bakar termodifikasi.

\section{DAFTAR PUSTAKA}

Aruan, I., Sangian, H. F., \& Tanauma, A. (2018). Efek Perubahan Struktur Pati Singkong Yang Dilakukan Pretreatment Dengan Larutan Ion Dan Gelombang Mikro Terhadap Produksi Gula. Jurnal MIPA, 7(1), 34.

Balat, M., Balat, H., \& Öz, C. (2008). Progress in bioethanol processing. Progress in Energy and Combustion Science, 34(5), 551573. https://doi.org/10.1016/j.pecs.2007 .11 .001

Demirbas, M. F., Bozbas, K., \& Balat, M. (2004). Carbon dioxide emission trends and environmental problems in Turkey. Energy Exploration and Exploitation, 22(5), 355-366. https://doi.org/10.1260/014459804 3026464

Dufey, A. (2006). Sustainable Markets Discussion Paper Number 2: Biofuels production, trade and 
sustainable development: Emerging Issues. (2).

Hsieh, W. D., Chen, R. H., Wu, T. L., \& Lin, T. H. (2002). Engine performance and pollutant emission of an SI engine using ethanol-gasoline blended fuels. Atmospheric Environment, 36(3), 403-410.

https://doi.org/10.1016/S13522310(01)00508-8

Martín, C., Galbe, M., Wahlbom, C. F., Hahn-Hägerdal, B., \& Jönsson, L. J. (2002). Ethanol production from enzymatic hydrolysates of sugarcane bagasse using recombinant xylose-utilising Saccharomyces cerevisiae. Enzyme and Microbial Technology, 31(3), 274-282.

https://doi.org/10.1016/S01410229(02)00112-6

McDowell, C. J., \& Powers, S. E. (2003). Mechanisms affecting the infiltration and distribution of ethanol-blended gasoline in the vadose zone. Environmental Science and Technology, 37(9), 1803-1810.

https://doi.org/10.1021/es0259761

Powers, S. E., Hunt, C. S., Heermann, S. E., Corseuil, H. X., Rice, D., \& Alvarez, P. J. J. (2001). The transport and fate of ethanol and BTEX in groundwater contaminated by gasohol. Critical Reviews in Environmental Science and Technology, 31(1), 79-123. https://doi.org/10.1080/200164910 89181
Sangian, H. F., Tunena, M., \& Pani, S. (2017). The study of isochoric subcritical water using power series: A potential of energy generation with ISCW reactor. AIP Conference Proceedings, 1887(September).

Sehe, M. Ri., Sangian, H. F., \& Tongkukut, S. H. . (2018). Studi Perbandingan Struktur Selulosa Dengan Pretreatment Larutan Ion Pada Kayu Cempaka (Elmerillia Ovalis). Jurnal MIPA, 7(1), 1. 